\title{
Ethanolic extract of Ocimum sanctum leaves reduced invasion and matrix metalloproteinase activity of head and neck cancer cell lines
}

Kusumawadee Utispan ${ }^{1,2^{*}}$, Nattisa Niyomtham ${ }^{2}$, Boon-ek Yingyongnarongkul ${ }^{3}$, and Sittichai Koontongkaew ${ }^{1,2}$

${ }^{1}$ Oral Biology Research Unit, Faculty of Dentistry, Thammasat University (Rangsit campus), Pathum Thani, Thailand

${ }^{2}$ Center of Excellence in Medicinal Herbs for Treatment of Oral Diseases, Faculty of Dentistry, Thammasat University, Thailand

${ }^{3}$ Department of Chemistry and Center of Excellence for Innovation in Chemistry, Faculty of Science, Ramkhamhaeng University, Thailand

* Corresponding author

E-mail: utispank@tu.ac.th $(\mathrm{KU})$ 
1 Abstract

Head and neck squamous cell carcinoma (HNSCC) has a yearly incidence of 600,000

3 cases worldwide with a low survival rate. Ocimum sanctum L. or Ocimum tenuiflorum L. (Holy

4 basil; Tulsi in Hindi), is a traditional medicine herb that demonstrates numerous effects,

5 including anti-oxidant, anti-microbial, and anti-tumor effects. The aim of this study was to

6 evaluate the anti-invasive effect of $O$. sanctum leaf extract on HNSCC cell lines. Ethanolic

7 extract of $O$. sanctum leaf (EEOS) was prepared and the phenolic compounds were identified

8 using high-performance liquid chromatography-electrospray ionization-time of flight-mass

9 spectrometry. Genetically-matched HNSCC cell lines derived from primary (HN30 and HN4)

10 and metastatic sites (HN31 and HN12) from the same patient were used in this study. The EEOS

11 cytotoxicity to the cell lines was determined using an MTT assay. The invasion and matrix

12 metalloproteinase (MMP)-2 and -9 activity of EEOS-treated cells were tested using a modified

13 Boyden chamber assay and zymography, respectively. We found that EEOS significantly

14 inhibited the invasion and MMP-2 and MMP-9 activity of HN4 and HN12 cells, but not HN30

15 and HN31 cells. Rosmarinic acid, caffeic acid, and apigenin were detected in EEOS. Moreover,

16 rosmarinic acid was found as the major phenolic compound. Therefore, EEOS exerted its anti-

17 invasive effect on HNSCC cells by attenuating MMP activity.

\section{Introduction}

Head and neck squamous cell carcinoma (HNSCC) originates in the epithelial cells of the

20 mucosal linings of the oral cavity, oropharynx, larynx, or hypopharynx [1]. HNSCC has an

21 incidence of 600,000 cases per year worldwide, with a 40-50\% mortality rate [2]. Similar to 22 other tumors, invasion and metastasis are the critical processes that indicate HNSCC 
aggressiveness [3]. Matrix metalloproteinase (MMPs) are the key enzymes involved in tumor invasion and metastasis. MMP-2 and MMP-9 destroy the basement membrane and degrade the extracellular matrix, promoting tumor invasion [4]. Although modern medicine has contributed to treating cancers by surgery, chemotherapy, and radiotherapy, these modalities have not

27 significantly changed the survival rate over the past three decades [5]. Thus, more effective 28 treatments for local and metastatic HNSCC are needed. English or Tulsi in Indian language [6], is a highly potent medicinal herb that is native throughout the eastern tropical countries including Thailand [7, 8]. O. sanctum is primarily composed of phytochemicals [9]. The fresh leaves and stem contain several flavonoids and phenolic compounds. Phenolic compounds such as apigenin, rosmarinic acid, cirsilineol,

34 cirsimaritin, isothymusin, and isothymonin have been detected in $O$. sanctum leaf extracts [10].

35 The phytochemicals in this plant varies depending on different growing, harvesting, extraction, and storage conditions [11]. The leaf extracts of $O$. sanctum have numerous medicinal effects

37 such as anti-oxidant [12, 13], wound healing [14], anti-microbial [15] and anti-tumorigenic 38 effects [11]. The ethanol extract of $O$. sanctum leaf (EEOS) has demonstrated anti-tumorigenic effects on several cancer types including gastric cancer [16], pancreatic cancer [17], non-small 40 cell lung cancer [18], and lung cancers [19, 20]. EEOS exhibited a variety of therapeutic effects 41 on tumor cells. EEOS decreased the expression of proteins involved in the proliferation, 42 invasion, and angiogenesis of carcinogen-induced rat gastric carcinoma [16]. Moreover, EEOS 43 inhibited cancer invasion and metastasis. EEOS reduced vascular endothelial growth factor 44 production and MMP-9 activity in metastatic-induced NCI-H460 non-small cell lung cancer cells 
52

\section{Materials and methods}

\section{Chemicals} constituents of the EEOS were identified. purchased from Merck (Darmstadt, Germany).

\section{O. sanctum leaf collection} BKF, Thailand.

\section{O. sanctum leaf extraction}

by inhibiting the phosphatidylinositol 3-kinase (PI3K)/Akt signaling pathway [18]. Similarly, when treated with EEOS, Lewis lung carcinoma cell MMP-9 activity was inhibited [20].

This evidence suggests that EEOS has a wide range of activity against tumor cells. However, there is no data concerning the effect of EEOS on HNSCC. We hypothesized that EEOS would reduce HNSCC cell invasion. Therefore, this study evaluated the toxicity and antiinvasive effectof EEOS on primary and metastatic HNSCC cell lines. Moreover, the chemical

Caffeic acid, rosmaric acid, and apigenin were purchased from Sigma-Aldrich (St. Louis, MO). Acetonitrile (HPLC grade), ethanol, methanol, and formic acid (all analytical grade) were

The $O$. sanctum leaves were collected in the Phra Pradaeng district, Samut Prakan province, in central Thailand, during the rainy season. The collected leaves were authenticated for taxonomic identification by The Forest Botany Division, Forest Herbarium-

The $O$. sanctum leaves were dried at room temperature and pulverized using a grinder. The O. sanctum powder was soaked in $95 \%$ ethanol for two weeks at room temperature. The extract 
was filtered through a $0.45 \mathrm{~nm}$ filter paper and concentrated using a rotary vacuum evaporator (Rotovapor R-215, BUCHI Labortechnik AG, Switzerland). The viscous residue was dried in a vacuum oven at $40^{\circ} \mathrm{C}$. The ethanolic extract of $O$. sanctum (EEOS) was stored as a powder at $4{ }^{\circ} \mathrm{C}$ until used.

\section{Cell culture}

Genetically-matched HNSCC cell lines derived from primary and metastatic sites from the same patient were provided by Professor Silvio Gutkind (Moores Cancer Center, Department of Pharmacology, UCSD, CA, USA). The HN30 and HN31 cells were obtained from primary pharynx lesions and lymph node metastases (T3N0M0), respectively. The HN4 and HN12 cells were obtained from primary tongue lesions and lymph node metastases (T4N1M0), respectively [21]. The cells were maintained in Dulbecco's Modified Eagle's Medium (DMEM) (Invitrogen, Carlsbad, CA) supplemented with $10 \%$ fetal bovine serum, $100 \mathrm{U} / \mathrm{ml}$ penicillin, $100 \mu \mathrm{g} / \mathrm{ml}$ streptomycin (Invitrogen), and an anti-fungal agent. The cells were cultured in a $37^{\circ} \mathrm{C}$ humidified $5 \% \mathrm{CO}_{2}$ atmosphere. The cells were passaged with $0.25 \%$ trypsin-EDTA when $90-100 \%$ confluent. Only cultures with at least $95 \%$ cell viability were used in the experiments.

\section{MTT assay} incubation, the amount of viable cells in each treatment group were determined using thiazolylblue tetrazolium bromide (MTT, Sigma). The medium was removed, $150 \mu 1$ of fresh 
88 incubated for $4 \mathrm{~h}$ at $37^{\circ} \mathrm{C}$ in a $5 \% \mathrm{CO}_{2}$ incubator. The precipitated formazan crystals were

89 solubilized in DMSO $(200 \mu \mathrm{l} /$ well $)$. The absorbance of the resulting solution was measured at

$90570 \mathrm{~nm}$ by a microplate reader (Tecan trading, Austria) and converted to percent viable cells

91 compared with control. Cell viability (\%) was determined as follows: cell viability $(\%)=$

92 (mean Abs570 $0_{\text {treated cells }}$ - mean Abs570 blank $) /\left(\right.$ mean Abs570 $0_{\text {control cells }}$ - mean Abs570 blank $) \times 100$.

93 Three independent experiments were performed.

\section{Invasion assay}

To evaluate cell invasion, an in vitro assay for cell invasion through Matrigel was performed using a blind-well Boyden chemotaxis chamber (Neuro Probe, Gaithersburg, MD) as

97 previously described [22]. Briefly, the upper surface of $13 \mu \mathrm{m}$ pore polycarbonate filters (Fisher

98 Scientific, Canada) was coated with Matrigel, a reconstituted basement membrane gel (Corning,

99 Tewksbury, MA) and placed between the upper and lower well plates of a blind-well

100 Boyden chemotaxis chamber. Growth medium was used as a source of chemoattractants in the

101 lower chamber. HNSCC cells $\left(8 \times 10^{4}\right.$ cells $)$ were resuspended in $0.4 \mathrm{mg} / \mathrm{ml}$ EEOS diluted in

102 DMEM containing 0.1\% BSA and were seeded into the upper well of the chamber. Cells treated

103 with DMEM containing 0.1\% BSA served as control. After $5 \mathrm{~h}$ incubation in a $37^{\circ} \mathrm{C}$ and $5 \%$

$104 \mathrm{CO}_{2}$ atmosphere incubator, the non-migrating cells on the upper surface of the filter were wiped

105 off with a cotton bud. The filters were fixed with $0.5 \%$ crystal violet in $25 \%$ methanol for

$10610 \mathrm{~min}$. The invaded cells on the lower surface of the filters were counted under a microscope at

$107400 \times$ magnification. Cell counting was performed by two investigators. Five randomly selected

108 fields were counted per filter in each group, and the counts were averaged. Three independent 109 experiments were performed. 


\section{Conditioned medium preparation and zymography}

HNSCC cells $\left(2 \times 10^{6}\right.$ cells) were cultured in 6 -well plates and incubated at $37^{\circ} \mathrm{C}$ for $24 \mathrm{~h}$.

112 After incubation, the wells were washed with PBS and treated with $0.4 \mathrm{mg} / \mathrm{ml}$ EEOS diluted in

127 MD). The gelatinolytic bands were quantified using GeneTools software (Syngene, Frederick,

128 MD). Three independent experiments were performed.

\section{9}

\section{HPLC-ESI-TOF-MS analysis of EEOS}

The $O$. sanctum extract was chemically analyzed using high-performance liquid chromatography coupled with electrospray ionization-time of flight-mass spectrometry (HPLC- 
133

134

135

136

137

138

139

140

141

142

143

144

145

146

147

an HPLC system (UltiMate ${ }^{\circledR} 3000$ system, Thermo Fisher Scientific, Sunnyvale, CA). Caffeic acid, rosmarinic acid, and apigenin standards were prepared (10, 50, 100, 150, 200, and 250 $\mu \mathrm{g} / \mathrm{ml}$ ). HPLC was performed using a reverse phase column (Symmetry C18 analysis column, 2.1 $\mathrm{mm} \times 150 \mathrm{~mm}$, and $5 \mu \mathrm{m}$ particle size). A gradient elution was performed with a mobile phase of $0.1 \%$ formic acid (Component $\mathrm{A}$ ) and $0.1 \%$ acetonitrile (Component B). Elution was performed at a $0.3 \mathrm{ml} / \mathrm{min}$ flow rate. The injection volume was $5 \mu \mathrm{l}$ and the column temperature was $40^{\circ} \mathrm{C}$. The components that were separated by the HPLC system were subjected to mass to charge ratio (m/z) analysis using a ESI-TOF-Ms system. ESI-TOF-MS was performed using a time of flight mass spectrometer (micrOTOF-Q-II, Bruker Daltonics, Germany). The ESI system negative-ion mode was used to generate $\mathrm{m} / \mathrm{z}$ in a range $50-1000$. The optimized mass spectrometric conditions were gas temperature $\left(200^{\circ} \mathrm{C}\right)$, drying gas flow rate $(8 \mathrm{l} / \mathrm{min})$, nebulizer gas pressure $(2 \mathrm{bar})$, and the capillary potential was $3000 \mathrm{~V}$. Quantitative determination of the EEOS phenolic components was performed using a standard calibration curve. The data was analyzed using DataAnalysis 4.0 software (Bruker Daltonics, Germany).

\section{Statistical analysis}

The results are presented as means and standard error of the mean (SEM). Statistical analysis was performed using one-way ANOVA followed by the Tukey's multiple comparisons test with Prism GraphPad 7.0 (GraphPad Software, La Jolla, CA). The significance level was set at 0.05 . 


\section{Results}

\section{Cytotoxic assessment of EEOS on the HNSCC cell lines}

The cytotoxic effect of EEOS on the HNSCC cell lines was evaluated using an MTT assay (Fig 1). EEOS (0.8 mg/ml) significantly decreased the HN30, HN31, HN4, and HN12 cell viability to approximately $40 \%, 53 \%, 52 \%$, and $40 \%$, respectively, of that of their controls $(P<$ 0.05). Whereas, $0.05,0.1,0.2$, and $0.4 \mathrm{mg} / \mathrm{ml}$ EEOS were non-toxic to the cell lines. Therefore, the HNSCC cell lines were treated with $0.4 \mathrm{mg} / \mathrm{ml}$ EEOS and their invasion and MMP-2 and-9 activity were evaluated.

\section{EEOS decreased metastatic HNSCC invasion}

We found that HN30 and HN31 cell line invasion was not significantly inhibited by the non-toxic dose of EEOS $(0.4 \mathrm{mg} / \mathrm{ml})$ compared with control $(P>0.05)$ (Figs $2 \mathrm{~A}$ and $\mathrm{B})$. In approximately $30 \%$ compared with control $(P<0.05)$ (Figs $2 \mathrm{C}$ and D).

\section{EEOS reduced MMP-2 and -9 activity of HNSCC cell lines}

MMP-2 and MMP-9 activity was detected and quantified as gelatinolytic bands and 167 arbitrary number of intensity, respectively. We found that $0.4 \mathrm{mg} / \mathrm{ml}$ EEOS treatment did not 168 alter MMP-2 and MMP-9 activity of HN30 and HN31 cells (Fig 3A). However, MMP-2 and MMP-9 activity of HN4 and HN12 cells were downregulated when treated with EEOS (Fig 3B).

170 Quantitative analysis of MMP activity revealed that the MMP-2 and MMP-9 activity in EEOS171 treated HN30 and HN31 cells and control cells were not significantly different $(P>0.05)($ Figs $1723 \mathrm{C}$ and D). Differently, $0.4 \mathrm{mg} / \mathrm{ml}$ EEOS significantly reduced HN4 and HN12 cell MMP-2 
173 activity to approximately $65 \%$ and $71 \%$, respectively, of that of the control cells $(P<0.05)$. In

174 addition, $0.4 \mathrm{mg} / \mathrm{ml}$ EEOS significantly reduced the MMP-9 activity of the HN4 and HN12 cells

175 to approximately $44 \%$ and $85 \%$, respectively, of that of the control cells $(P<0.05)$ (Figs $3 \mathrm{C}$ and

176 D).

$177 \quad$ HPLC analysis of EEOS

178

179

180

181

182

183

184

185

186

187

188

189

190

191

192

193

194

The HPLC retention times of caffeic acid, rosmarinic acid, and apigenin standards were determined (Fig 4A). The EEOS chromatograms demonstrated peaks 1, 2, and 3 with retention times that corresponded to those of the caffeic acid, rosmarinic acid, and apigenin standards, respectively (Fig 4B).

\section{Structural identification of the compounds in EEOS}

HPLC-ESI-MS parameters were optimized and used to profile the EEOS. The selected 3 compounds in EEOS were putatively identified by comparison to the database (Table 1). Moreover, structures of the putative compounds were drawn by comparison to the known structure of standard compounds. The result revealed that compounds 1,2 , and 3 were caffeic acid, rosmarinic acid, and apigenin, respectively (Figs 5A and A). Quantification of the EEOS caffeic acid, rosmarinic acid, and apigenin indicated that rosmarinic acid was the major phenolic component (Fig 5C). 
195

196

\begin{tabular}{|c|l|c|c|c|c|}
\hline Compounds & \multicolumn{1}{|c|}{$\begin{array}{c}\text { Putative } \\
\text { identification }\end{array}$} & $\begin{array}{c}\text { Retention } \\
\text { time (min) }\end{array}$ & $\begin{array}{c}\text { Empirical } \\
\text { formula }\end{array}$ & $\begin{array}{c}\text { Theoretical } \\
m / z\end{array}$ & $\mathrm{~m} / \mathrm{z}$ \\
\hline 1 & Caffeic acid & 9.40 & $\mathrm{C}_{9} \mathrm{H}_{8} \mathrm{O}_{4}$ & 179.0349 & 179.0355 \\
\hline 2 & Rosmarinic acid & 27.66 & $\mathrm{C}_{18} \mathrm{H}_{16} \mathrm{O}_{8}$ & 359.0772 & 359.0764 \\
\hline 3 & Apigenin & 46.63 & $\mathrm{C}_{15} \mathrm{H}_{10} \mathrm{O}_{5}$ & 269.0455 & 269.0449 \\
\hline
\end{tabular}

Table 1. HPLC-ESI-MS analysis of EEOS. Elucidation of empirical formulas and putative identification of each compound.
197

198

199

200

201

202

203

204

205

206

207

208

209

210

211

\section{Discussion}

The present study investigated the effects of crude $O$. sanctum leaf extract on HNSCC invasiveness. EEOS cytotoxicity on the HNSCC cell lines was evaluated to determine the concentration to be used in subsequent experiments. A previous study reported that $0.2 \mathrm{mg} / \mathrm{ml}$ EEOS demonstrated a significant cytotoxic effect on a lung cancer cell line (A549) and mouse Lewis lung carcinoma cells [19]. However, $0.2 \mathrm{mg} / \mathrm{ml}$ EEOS was non-toxic to NCI-H460 nonsmall cell lung cancer cells [18]. Our findings indicated that $0.05,0.1,0.2$, and $0.4 \mathrm{mg} / \mathrm{ml}$ EEOS did not reduce HNSCC cell viability whereas, $0.8 \mathrm{mg} / \mathrm{ml}$ EEOS was toxic to the cell lines evaluated. Thus, the cytotoxic effect of EEOS may be cell type-dependent.

MMP-2 and MMP-9 activity is important in initiating tumor invasion [4]. Several studies have reported the expression and role of MMP-2 and MMP-9 in HNSCC aggressiveness [24-27]. We evaluated the effect of EEOS on HNSCC invasion and MMP activity. We found that EEOS decreased HN4 and HN12 cell invasion by attenuating MMP-2 and MMP-9 activity. In contrast, there was no significant change in HN30 and HN31 cell invasion or MMP activity after EEOS 
212 treatment. Our results indicated that EEOS regulation of HNSCC invasiveness may be stage-

213 dependent. These results imply that EEOS may have a potent role in inhibiting the invasiveness

214 of a stage IV tumor. A study demonstrated that EEOS reduced the metastatic activity of Lewis

215 lung carcinoma cell-injected mice [20]. They found that EEOS inhibited cancer invasion and

216 MMP-9 activity, but not that of MMP-2. Another group confirmed that EEOS reduced MMP-9

217 and urokinase plasminogen activator activity in non-small cell lung cancer cells (NCI-H460) by

218 inhibiting the PI3K/Akt signalling pathway [18]. MMP-9 production in HNSCC cell is induced

219 through various signalling pathways, including epidermal growth factor receptor (EGFR),

220 mitogen-activated kinase (MAPK) and PI3K/Akt [26, 28]. This suggests that EEOS may regulate

221 MMP-2 and MMP-9 activity by targeting EGFR, MAPK, or PI3K/Akt pathways, leading to

222 decreased HNSCC invasion.

The chemical composition of EEOS has been reported [29]. They found that EEOS was

224 composed of several phenolic compounds and flavonoids, including rosmarinic acid and

225 apigenin. Our results confirmed that the EEOS used in the present study contained rosmarinic

226 acid, apigenin, and caffeic acid. Moreover, rosmarinic acid was the major phenolic component in

227 our EEOS. Rosmarinic acid inhibited colon cancer invasion [30] colorectal cancer metastasis

228 [31] by inhibiting MMP-2 and MMP-9 activity. These findings imply that the rosmarinic acid in

229 EEOS may be a key factor in suppressing HNSCC cell invasion and MMP activity. Future

230 studies should investigate the mechanism of rosmarinic acid and the other EEOS-derived

231 components in suppressing HNSCC aggressiveness. 


\section{Conclusions}

Taken together, the present study demonstrated the cytotoxic and anti-tumorigenic effects

234 of EEOS on HNSCC invasion and MMP-2 and MMP-9 activity. Interestingly, EEOS selectively

235 regulated the invasion and MMP activity of HN4 and HN12 cells that were derived from stage

236 IV tumors. We showed that the phenolic compounds rosmarinic acid, caffeic acid, and apigenin

237 were present in EEOS. Moreover, rosmarinic acid was found as a major phenolic component.

238 These results suggest that EEOS may be used as an alternative therapeutic agent in clinical

239 research. However, the anti-tumorigenic mechanisms of the active compounds in EEOS require

240 further investigation.

\section{Acknowledgements}

The authors thank Professor Silvio Gutkind (Moores Cancer Center, Department of

243 Pharmacology, UCSD, CA, USA) for the HNSCC cell lines used in our study. We thank Miss

244 Hataichanok Yindeesompong, Miss Parncheewee Boonyawattananun, and Miss Nudda

245 Khamrapich for technical assistance. We thank Dr. Amornmart Jaratrungtawee for HPLC-ESI-

246 TOF-MS technical advice. The English editing of this manuscript was kindly performed by Dr.

247 Kevin Tompkins, Office of Research Affairs, Faculty of Dentistry, Chulalongkorn University.

\section{References}

249 1. Argiris A, Karamouzis MV, Raben D, Ferris RL. Head and neck cancer. Lancet. 250 2008;371(9625):1695-709. doi: 10.1016/S0140-6736(08)60728-X. PubMed PMID: 18486742.

251 2. Ferlay J, Soerjomataram I, Dikshit R, Eser S, Mathers C, Rebelo M, et al. Cancer 252 incidence and mortality worldwide: sources, methods and major patterns in GLOBOCAN 2012. 
253 International journal of cancer. 2015;136(5):E359-86. doi: 10.1002/ijc.29210. PubMed PMID:

25425220842.

255 3. Leemans CR, Snijders PJF, Brakenhoff RH. The molecular landscape of head and neck

256 cancer. Nature reviews Cancer. 2018;18(5):269-82. doi: 10.1038/nrc.2018.11. PubMed PMID:

25729497144.

258 4. Koontongkaew S. The tumor microenvironment contribution to development, growth, 259 invasion and metastasis of head and neck squamous cell carcinomas. Journal of Cancer. 260 2013;4(1):66-83. doi: 10.7150/jca.5112. PubMed PMID: 23386906; PubMed Central PMCID: 261 PMC3564248.

262 5. Kozakiewicz P, Grzybowska-Szatkowska L. Application of molecular targeted therapies 263 in the treatment of head and neck squamous cell carcinoma. Oncology letters. 2018;15(5):7497264 505. doi: 10.3892/ol.2018.8300. PubMed PMID: 29725456; PubMed Central PMCID: 265 PMC5920345.

266 6. Baliga MS, Jimmy R, Thilakchand KR, Sunitha V, Bhat NR, Saldanha E, et al. Ocimum 267 sanctum L (Holy Basil or Tulsi) and its phytochemicals in the prevention and treatment of 268 cancer. Nutrition and cancer. 2013;65 Suppl 1:26-35. doi: 10.1080/01635581.2013.785010. 269 PubMed PMID: 23682780.

270 7. Bast F, Rani P, Meena D. Chloroplast DNA phylogeography of holy basil (Ocimum 271 tenuiflorum) in Indian subcontinent. TheScientificWorldJournal. 2014;2014:847482. doi: 272 10.1155/2014/847482. PubMed PMID: 24523650; PubMed Central PMCID: PMC3910118.

273 8. Suanarunsawat T, Anantasomboon G, Piewbang C. Anti-diabetic and anti-oxidative 274 activity of fixed oil extracted from Ocimum sanctum L. leaves in diabetic rats. Experimental and 
275 therapeutic medicine. 2016;11(3):832-40. doi: 10.3892/etm.2016.2991. PubMed PMID:

$27626998000 ;$ PubMed Central PMCID: PMC4774317.

277 9. Pattanayak P, Behera P, Das D, Panda SK. Ocimum sanctum Linn. A reservoir plant for

278 therapeutic applications: An overview. Pharmacognosy reviews. 2010;4(7):95-105. doi:

279 10.4103/0973-7847.65323. PubMed PMID: 22228948; PubMed Central PMCID: PMC3249909.

280 10. Gupta SK, Prakash J, Srivastava S. Validation of traditional claim of Tulsi, Ocimum

281 sanctum Linn. as a medicinal plant. Indian journal of experimental biology. 2002;40(7):765-73.

282 PubMed PMID: 12597545.

283 11. Bhattacharyya P, Bishayee A. Ocimum sanctum Linn. (Tulsi): an ethnomedicinal plant

284 for the prevention and treatment of cancer. Anti-cancer drugs. 2013;24(7):659-66. doi:

285 10.1097/CAD.0b013e328361aca1. PubMed PMID: 23629478.

286 12. Kelm MA, Nair MG, Strasburg GM, DeWitt DL. Antioxidant and cyclooxygenase

287 inhibitory phenolic compounds from Ocimum sanctum Linn. Phytomedicine : international

288 journal of phytotherapy and phytopharmacology. 2000;7(1):7-13. doi: 10.1016/S0944-

289 7113(00)80015-X. PubMed PMID: 10782484.

290 13. Manikandan P, Vidjaya Letchoumy P, Prathiba D, Nagini S. Combinatorial 291 chemopreventive effect of Azadirachta indica and Ocimum sanctum on oxidant-antioxidant 292 status, cell proliferation, apoptosis and angiogenesis in a rat forestomach carcinogenesis model.

293 Singapore medical journal. 2008;49(10):814-22. PubMed PMID: 18946617.

294 14. Goel A, Kumar S, Singh DK, Bhatia AK. Wound healing potential of Ocimum sanctum 295 Linn. with induction of tumor necrosis factor-alpha. Indian journal of experimental biology. 296 2010;48(4):402-6. PubMed PMID: 20726339. 
297 15. Eswar P, Devaraj CG, Agarwal P. Anti-microbial Activity of Tulsi \{Ocimum Sanctum

298 (Linn.) $\}$ Extract on a Periodontal Pathogen in Human Dental Plaque: An Invitro Study. Journal

299 of clinical and diagnostic research : JCDR. 2016;10(3):ZC53-6. doi:

300 10.7860/JCDR/2016/16214.7468. PubMed PMID: 27135002; PubMed Central PMCID:

$301 \quad$ PMC4843387.

302 16. Manikandan P, Vidjaya Letchoumy P, Prathiba D, Nagini S. Proliferation, angiogenesis

303 and apoptosis-associated proteins are molecular targets for chemoprevention of MNNG-induced

304 gastric carcinogenesis by ethanolic Ocimum sanctum leaf extract. Singapore medical journal.

305 2007;48(7):645-51. PubMed PMID: 17609827.

306 17. Shimizu T, Torres MP, Chakraborty S, Souchek JJ, Rachagani S, Kaur S, et al. Holy

307 Basil leaf extract decreases tumorigenicity and metastasis of aggressive human pancreatic cancer

308 cells in vitro and in vivo: potential role in therapy. Cancer letters. 2013;336(2):270-80. doi:

309 10.1016/j.canlet.2013.03.017. PubMed PMID: 23523869; PubMed Central PMCID:

310 PMC3700662.

311 18. Kwak TK, Sohn EJ, Kim S, Won G, Choi JU, Jeong K, et al. Inhibitory effect of ethanol

312 extract of Ocimum sanctum on osteopontin mediated metastasis of NCI-H460 non-small cell

313 lung cancer cells. BMC complementary and alternative medicine. 2014;14:419. doi:

314 10.1186/1472-6882-14-419. PubMed PMID: 25345853; PubMed Central PMCID:

315 PMC4219006.

316 19. Magesh V, Lee JC, Ahn KS, Lee HJ, Lee HJ, Lee EO, et al. Ocimum sanctum induces

317 apoptosis in A549 lung cancer cells and suppresses the in vivo growth of Lewis lung carcinoma

318 cells. Phytotherapy research : PTR. 2009;23(10):1385-91. doi: 10.1002/ptr.2784. PubMed

PMID: 19277950. 
320 20. Kim SC, Magesh V, Jeong SJ, Lee HJ, Ahn KS, Lee HJ, et al. Ethanol extract of Ocimum

321 sanctum exerts anti-metastatic activity through inactivation of matrix metalloproteinase-9 and

322 enhancement of anti-oxidant enzymes. Food and chemical toxicology : an international journal

323 published for the British Industrial Biological Research Association. 2010;48(6):1478-82. doi:

324 10.1016/j.fct.2010.03.014. PubMed PMID: 20233602.

325 21. Cardinali M, Pietraszkiewicz H, Ensley JF, Robbins KC. Tyrosine phosphorylation as a 326 marker for aberrantly regulated growth-promoting pathways in cell lines derived from head and 327 neck malignancies. International journal of cancer. 1995;61(1):98-103. PubMed PMID: 3287705939.

329 22. Albini A, Iwamoto Y, Kleinman HK, Martin GR, Aaronson SA, Kozlowski JM, et al. A 330 rapid in vitro assay for quantitating the invasive potential of tumor cells. Cancer research. 331 1987;47(12):3239-45. PubMed PMID: 2438036.

332 23. Thomas GJ, Lewis MP, Hart IR, Marshall JF, Speight PM. AlphaVbeta6 integrin 333 promotes invasion of squamous carcinoma cells through up-regulation of matrix 334 metalloproteinase-9. International journal of cancer. 2001;92(5):641-50. PubMed PMID: 33511340566.

336 24. de Vicente JC, Fresno MF, Villalain L, Vega JA, Hernandez Vallejo G. Expression and 337 clinical significance of matrix metalloproteinase-2 and matrix metalloproteinase-9 in oral 338 squamous cell carcinoma. Oral oncology. 2005;41(3):283-93. doi: 339 10.1016/j.oraloncology.2004.08.013. PubMed PMID: 15743691.

340 25. Kato K, Hara A, Kuno T, Kitaori N, Huilan Z, Mori H, et al. Matrix metalloproteinases 2 341 and 9 in oral squamous cell carcinomas: manifestation and localization of their activity. Journal 
342 of cancer research and clinical oncology. 2005;131(6):340-6. doi: 10.1007/s00432-004-0654-8.

343 PubMed PMID: 15614523.

344 26. Koontongkaew S, Amornphimoltham P, Monthanpisut P, Saensuk T, Leelakriangsak M.

345 Fibroblasts and extracellular matrix differently modulate MMP activation by primary and 346 metastatic head and neck cancer cells. Medical oncology. 2012;29(2):690-703. doi:

347 10.1007/s12032-011-9871-6. PubMed PMID: 21380786.

348 27. Patel BP, Shah SV, Shukla SN, Shah PM, Patel PS. Clinical significance of MMP-2 and

349 MMP-9 in patients with oral cancer. Head \& neck. 2007;29(6):564-72. doi: 10.1002/hed.20561.

350 PubMed PMID: 17252594.

351 28. P Oc, Wongkajornsilp A, Rhys-Evans PH, Eccles SA. Signaling pathways required for

352 matrix metalloproteinase-9 induction by betacellulin in head-and-neck squamous carcinoma 353 cells. International journal of cancer. 2004;111(2):174-83. doi: 10.1002/ijc.20228. PubMed

354 PMID: 15197768.

355 29. Venuprasad MP, Kandikattu HK, Razack S, Amruta N, Khanum F. Chemical 356 composition of Ocimum sanctum by LC-ESI-MS/MS analysis and its protective effects against 357 smoke induced lung and neuronal tissue damage in rats. Biomedicine \& pharmacotherapy $=$ 358 Biomedecine \& pharmacotherapie. 2017;91:1-12. doi: 10.1016/j.biopha.2017.04.011. PubMed 359 PMID: 28433747.

360 30. $\mathrm{Xu} \mathrm{Y,} \mathrm{Xu} \mathrm{G,} \mathrm{Liu} \mathrm{L,} \mathrm{Xu} \mathrm{D,} \mathrm{Liu} \mathrm{J.} \mathrm{Anti-invasion} \mathrm{effect} \mathrm{of} \mathrm{rosmarinic} \mathrm{acid} \mathrm{via} \mathrm{the}$ 361 extracellular signal-regulated kinase and oxidation-reduction pathway in Ls174-T cells. Journal 362 of cellular biochemistry. 2010;111(2):370-9. doi: 10.1002/jcb.22708. PubMed PMID: 20506543. 
363 31. Han YH, Kee JY, Hong SH. Rosmarinic Acid Activates AMPK to Inhibit Metastasis of

364 Colorectal Cancer. Frontiers in pharmacology. 2018;9:68. doi: 10.3389/fphar.2018.00068.

365 PubMed PMID: 29459827; PubMed Central PMCID: PMC5807338. 


\section{Figure legends}

Fig 1. Cytotoxic evaluation of EEOS on HNSCC cells measured by MTT assay. EEOS in a range of concentrations were used to treat HN30 (A), HN31 (B), HN4 (C), and HN12 (D) cells for $72 \mathrm{~h}$. Bars represent means $\pm \operatorname{SEM}(\mathrm{n}=3)$. * indicates $p<0.05$ compared with control.

Fig 2. EEOS decreased HNSCC cell invasion. A non-cytotoxic dose of EEOS was used to treat HN30 (A), HN31 (B), HN4 (C), and HN12 (D) cells and evaluated cell invasion. Bars represent means \pm SEM $(\mathrm{n}=3) . *$ indicates $p<0.05$ compared with control.

Fig 3. EEOS reduced MMP activity. The HNSCC cell lines were treated with $0.4 \mathrm{mg} / \mathrm{ml}$ EEOS for $48 \mathrm{~h}$ and the MMP activity in the conditioned media of HN30 and HN31 cells (A), and HN4 and HN12 cells (B) were detected using zymography. GeneTools software was used to quantify the gelatinolytic bands of MMP-2 (C) and MMP-9 (D) activity. Bars represent means \pm SEM $(\mathrm{n}=3)$. * indicates $p<0.05$ compared with the control.

Fig 4. HPLC analysis of EEOS. Chromatogram of standard phenolic compounds (A) and the compounds detected in EEOS (B) are shown.

Fig 5. ESI-TOF-MS analysis of the compounds in EEOS. The structures of standard phenolic compounds (A) and the compounds in EEOS (B) analyzed from HPLC were identified. Quantification of the compounds in EEOS (C). 

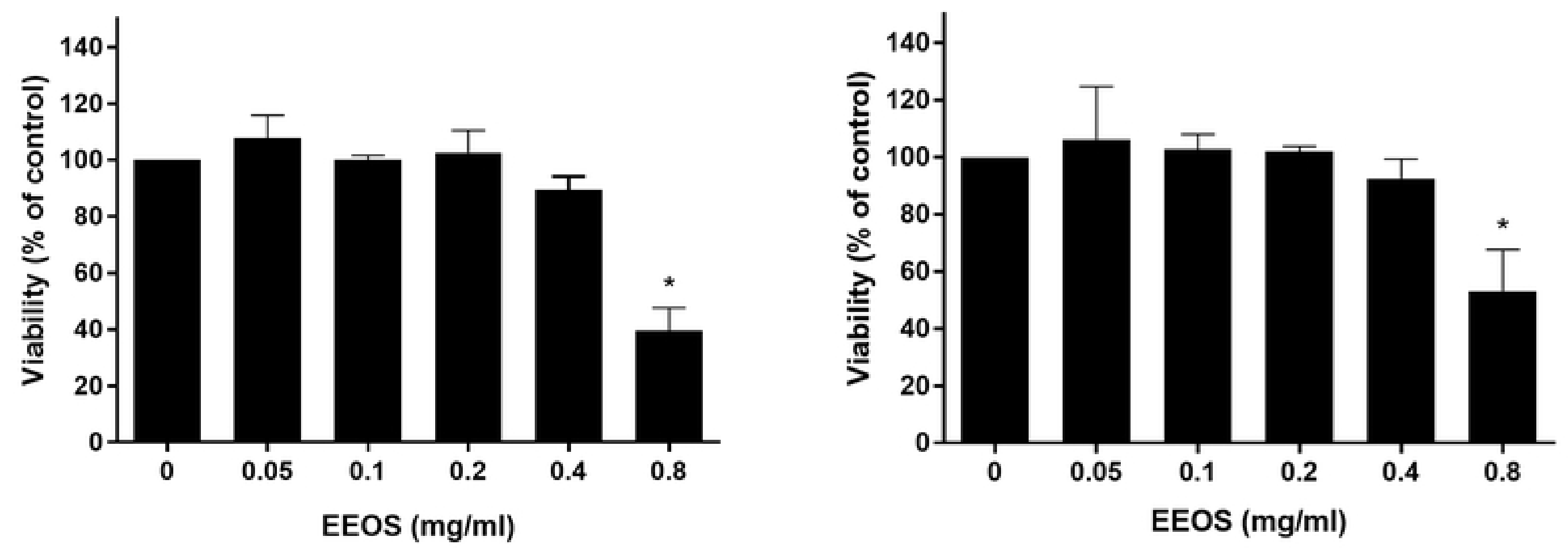

C

D

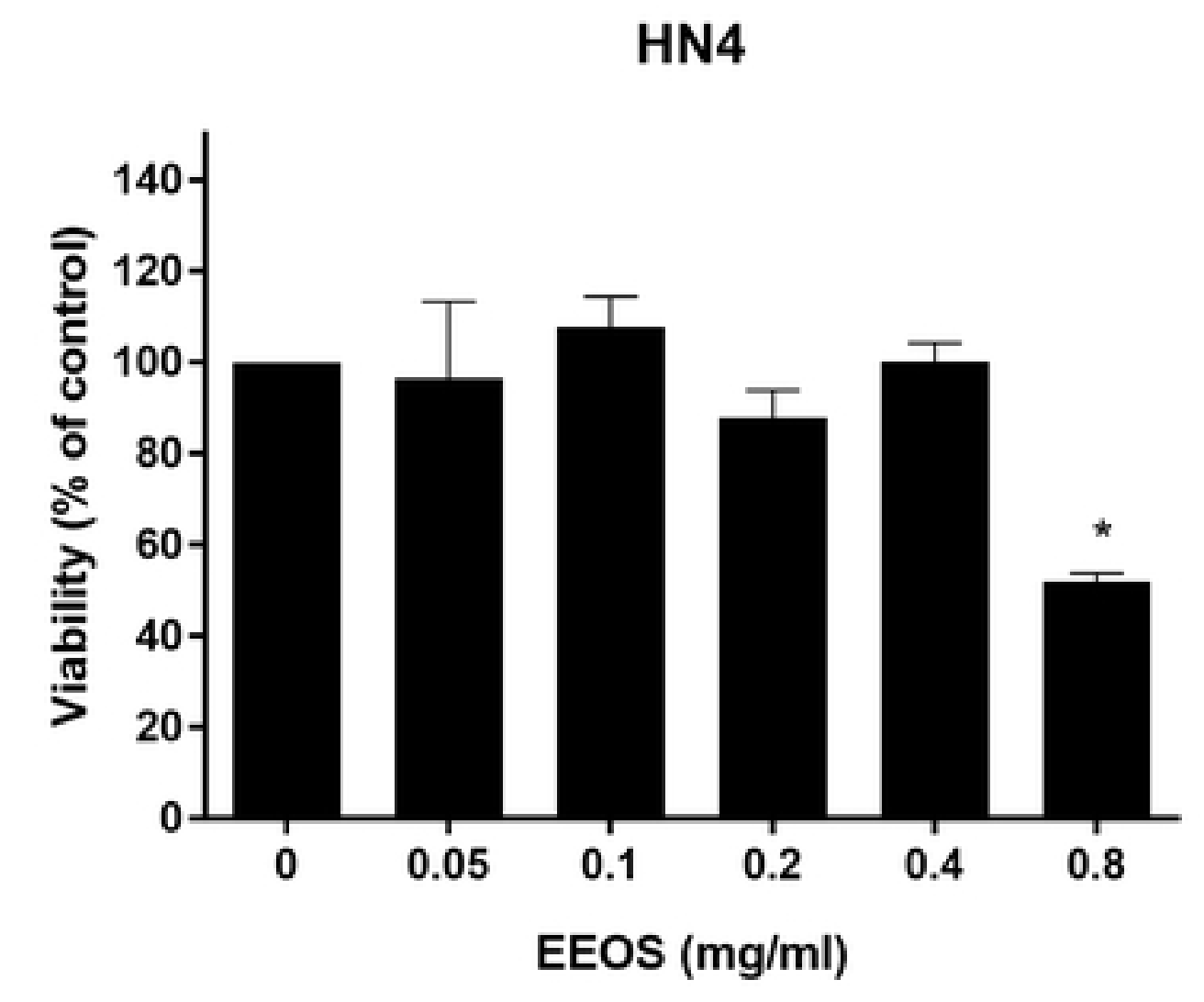

\section{HN4}

HN12

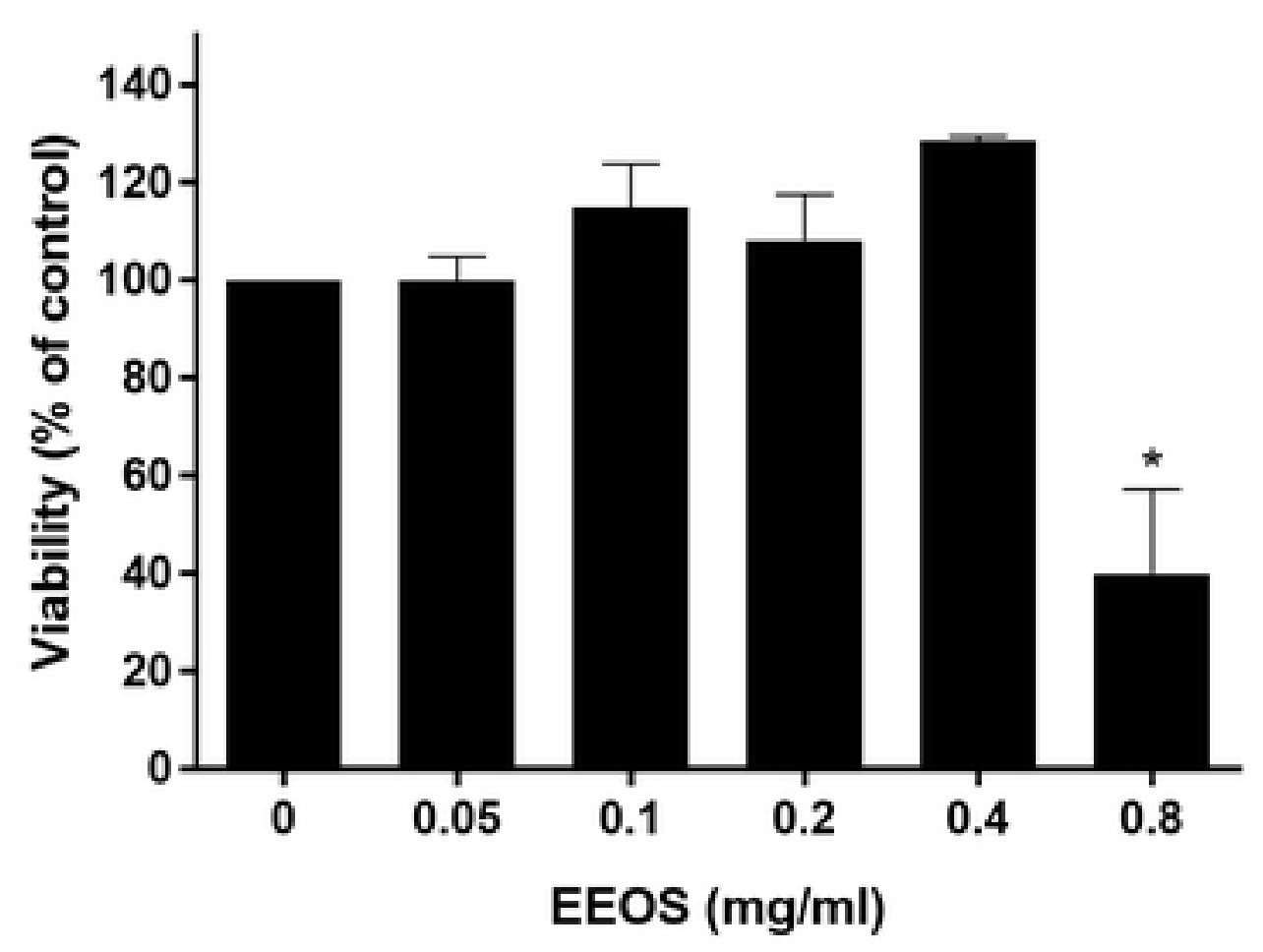

Fig 1 
A

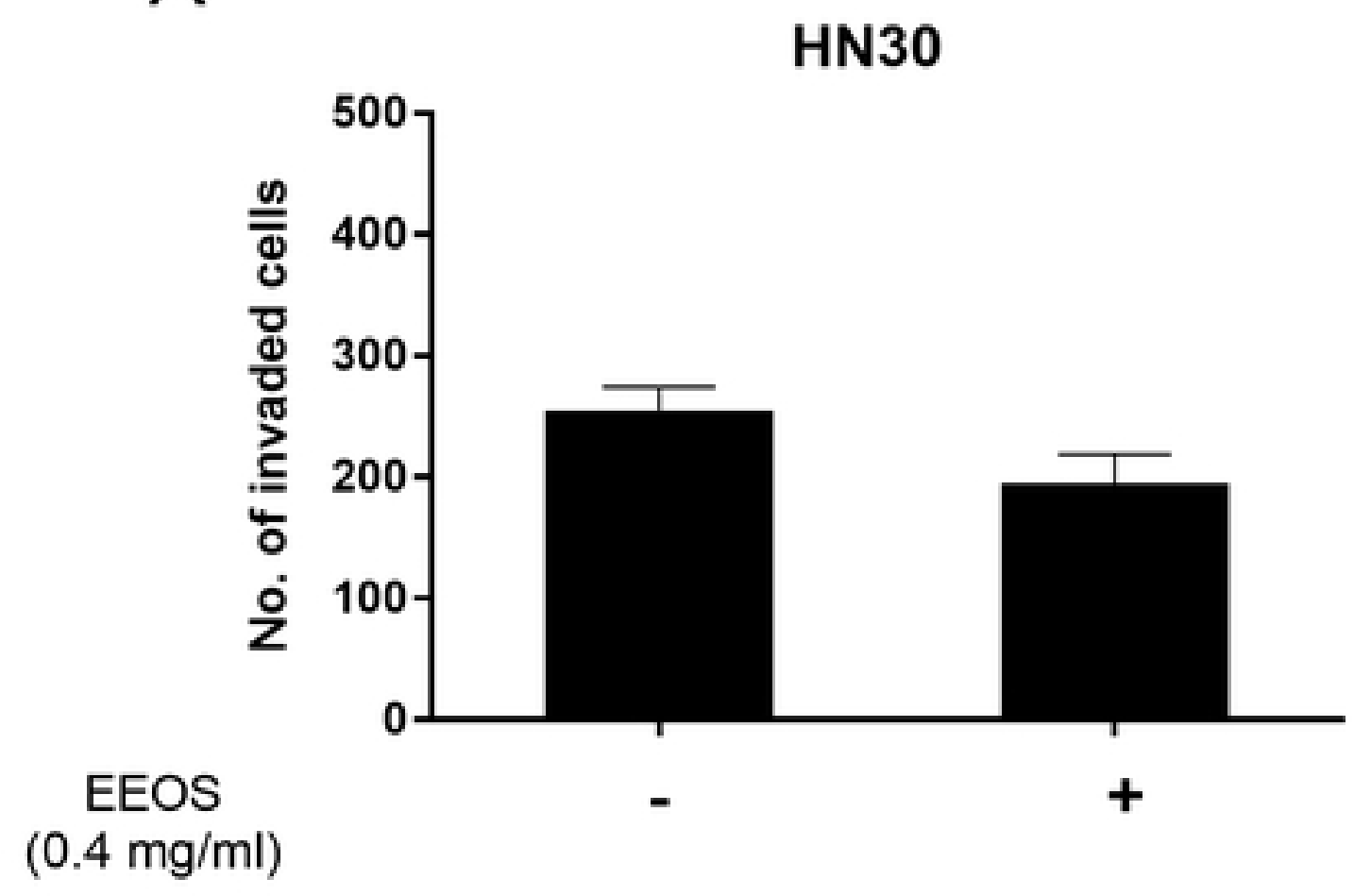

C

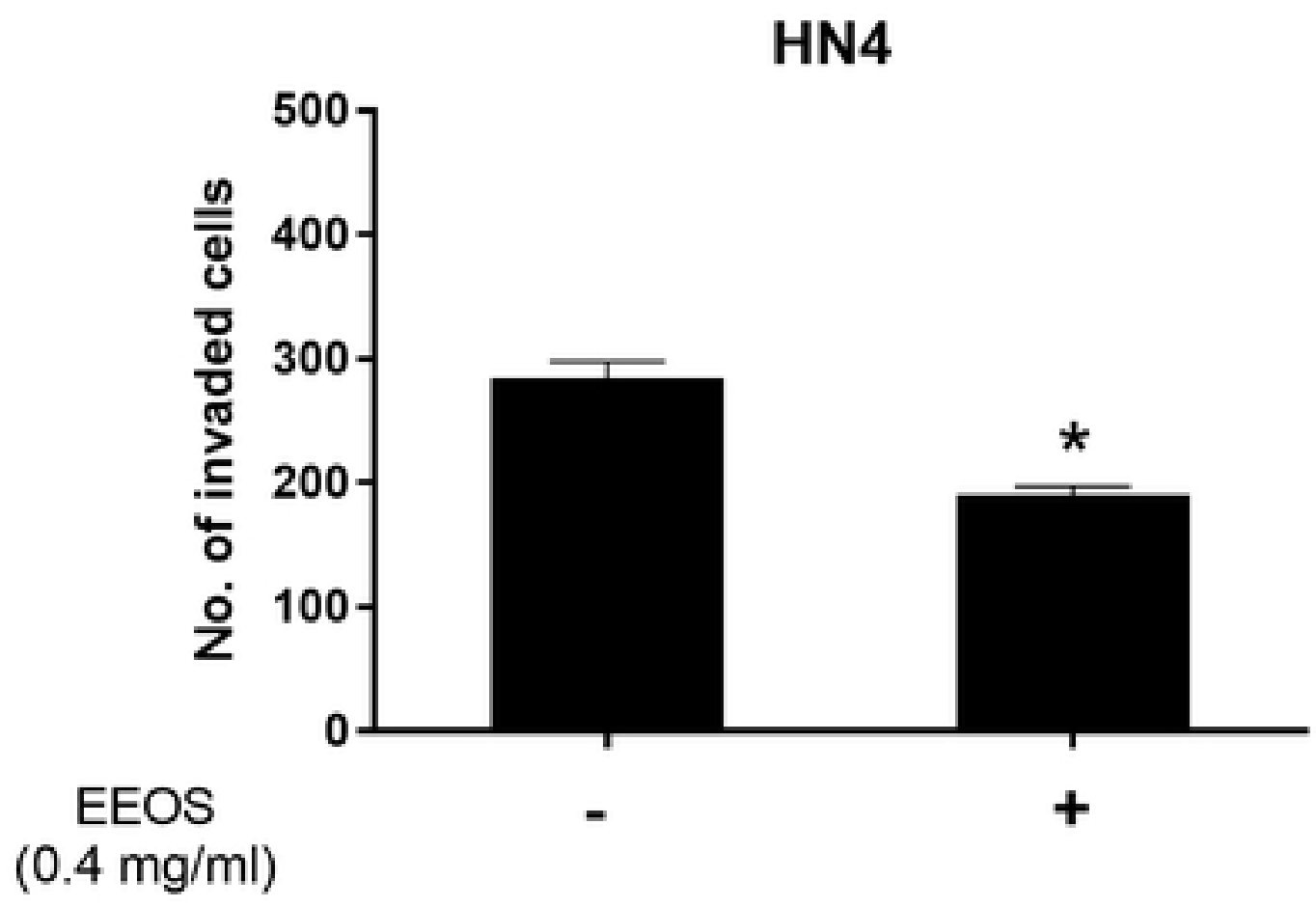

B

HN31

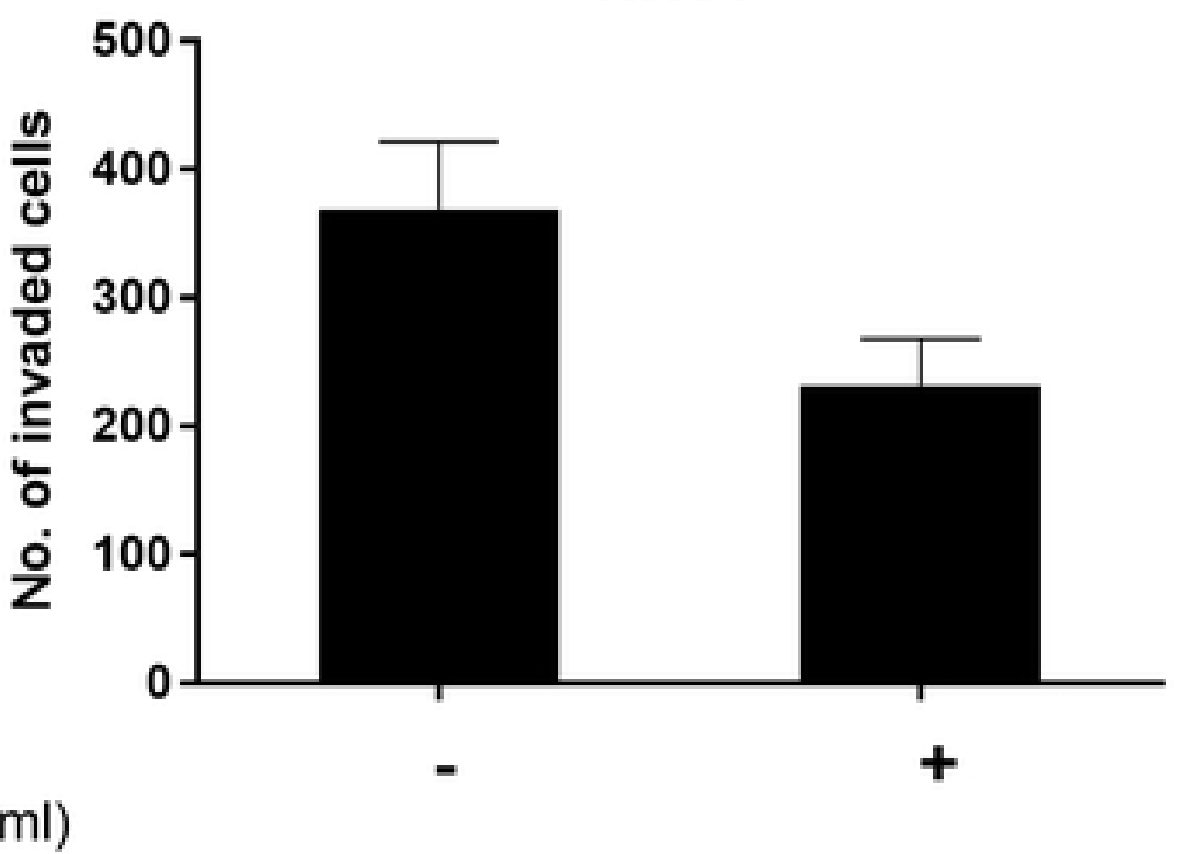

$(0.4 \mathrm{mg} / \mathrm{ml})$

D

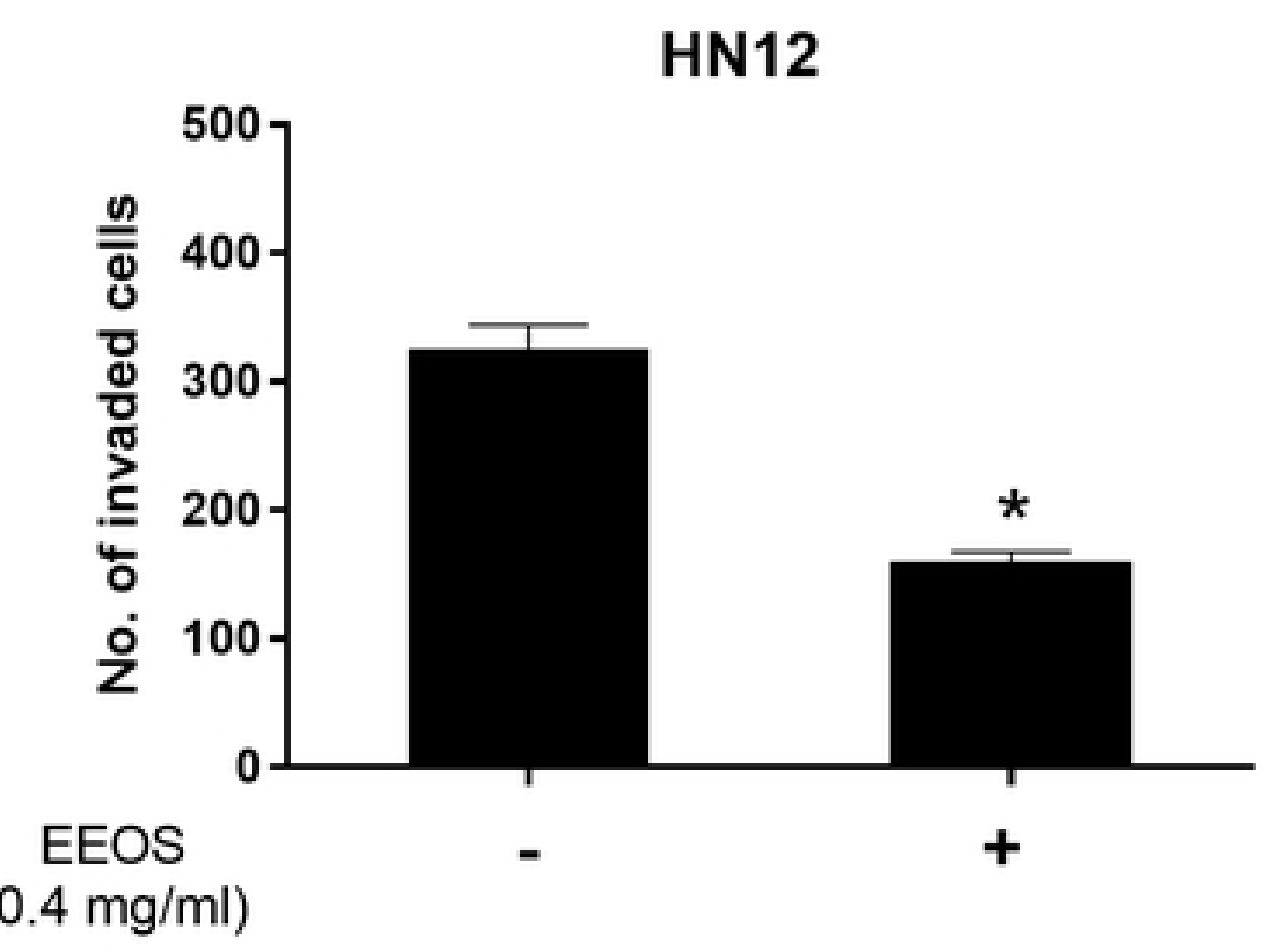

Fig 2 
A

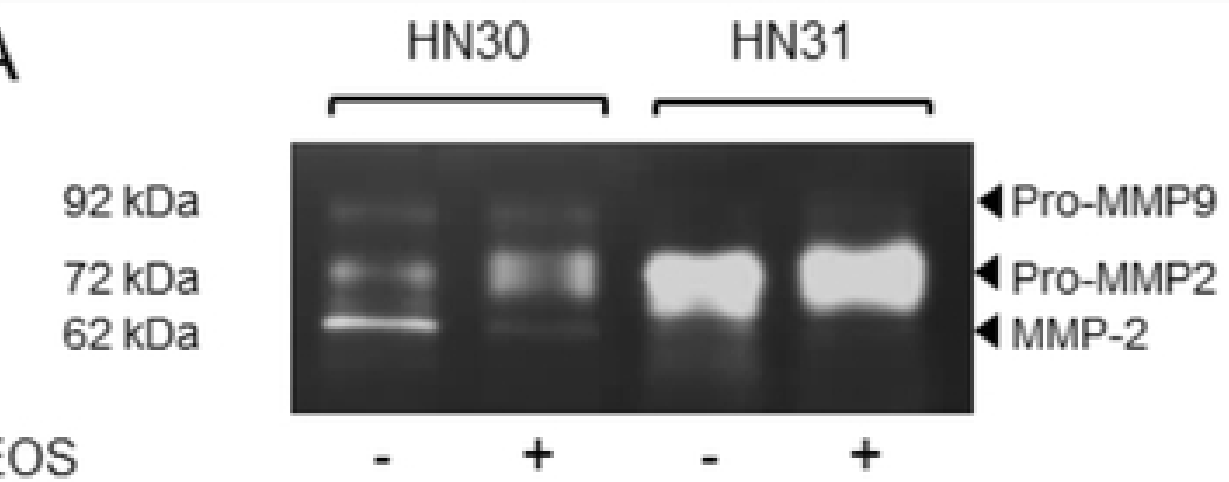

EEOS

C

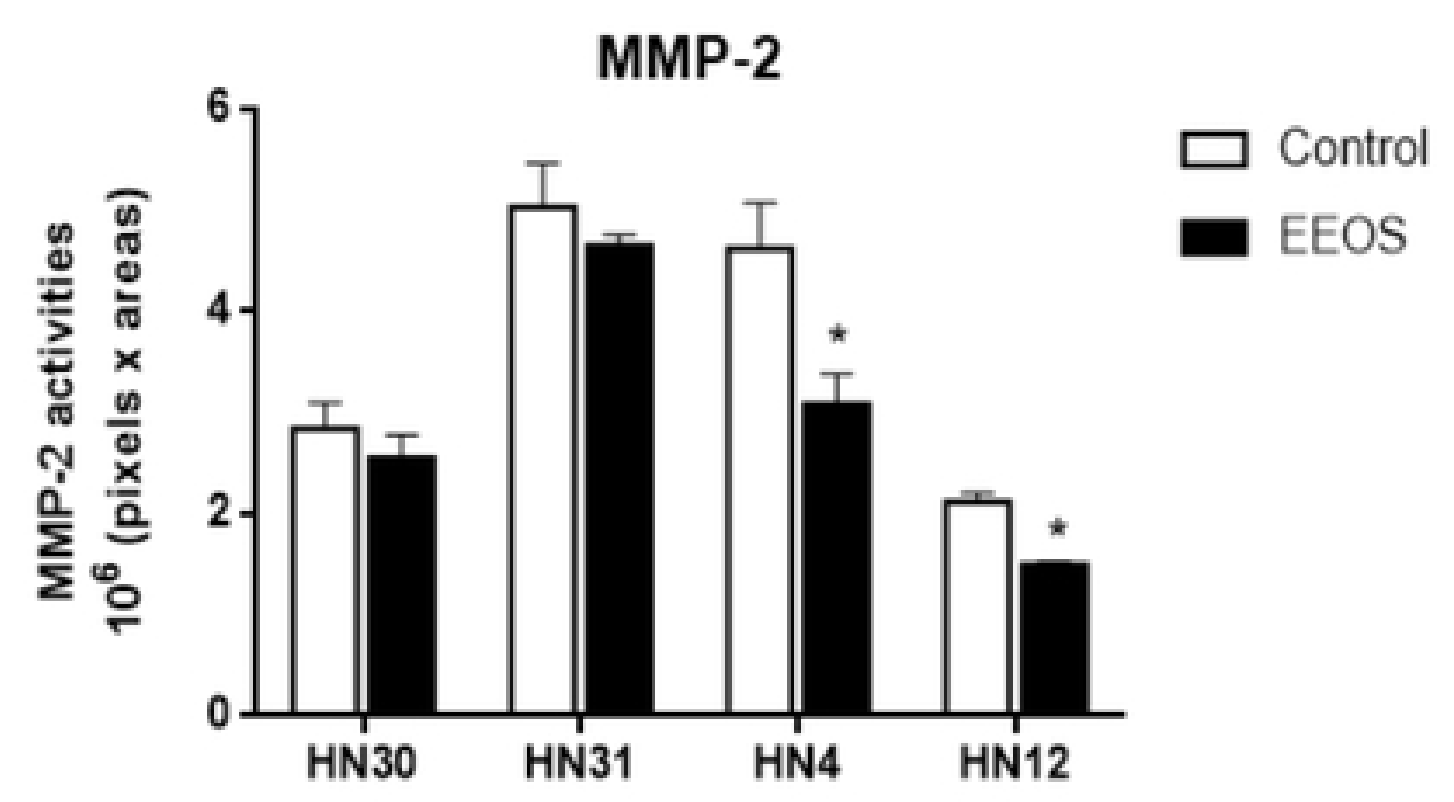

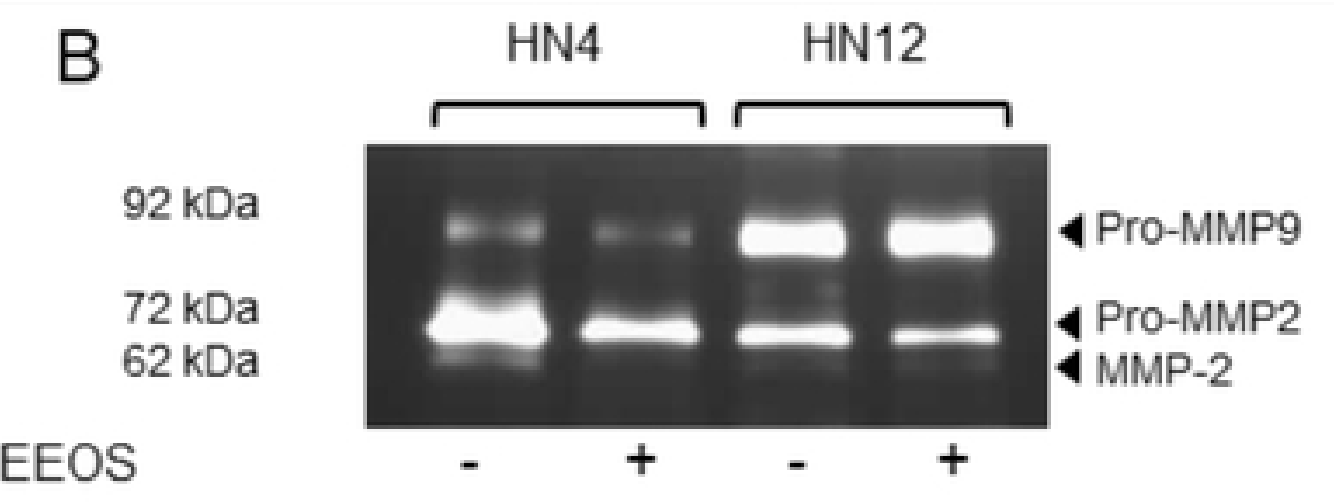

D

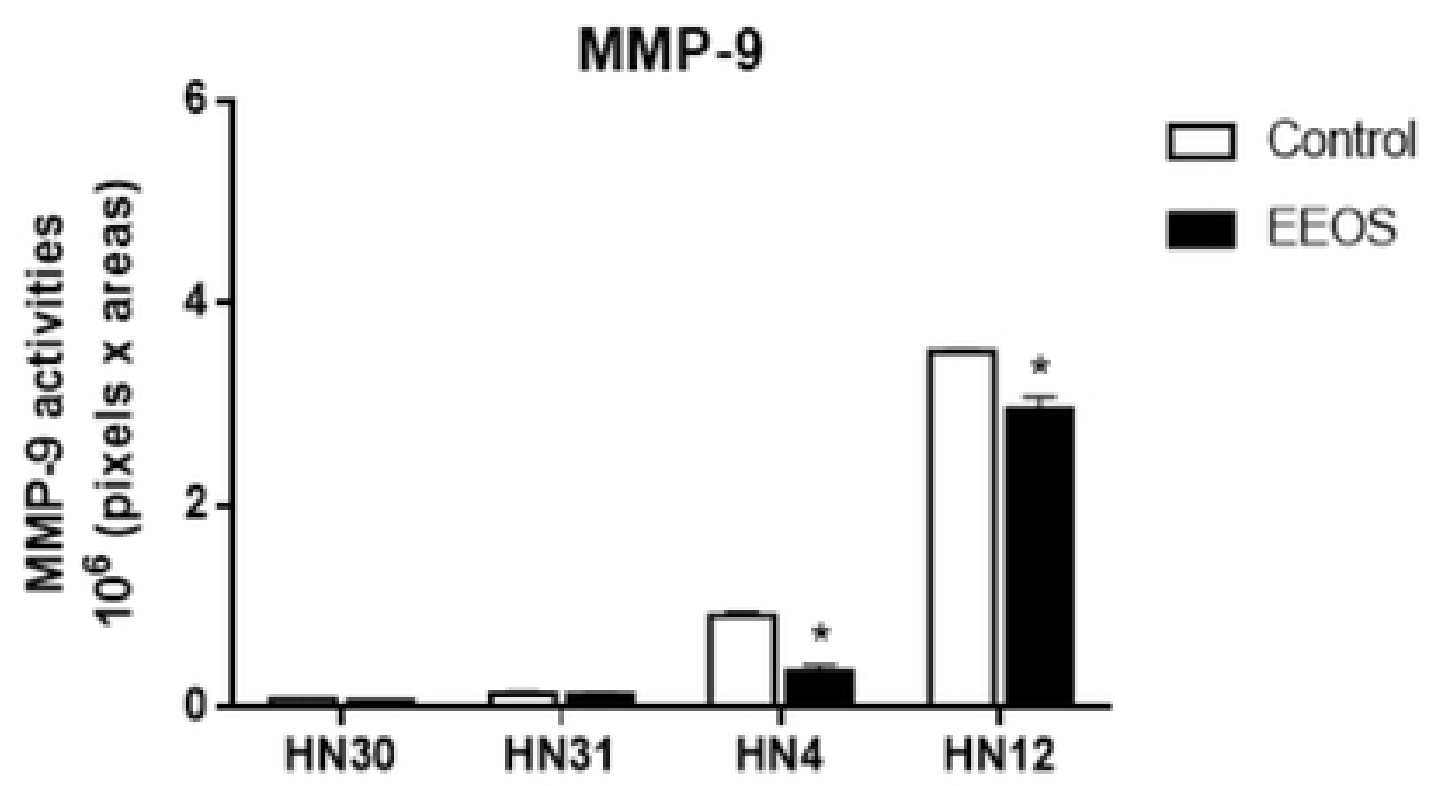

Fig 3 
A

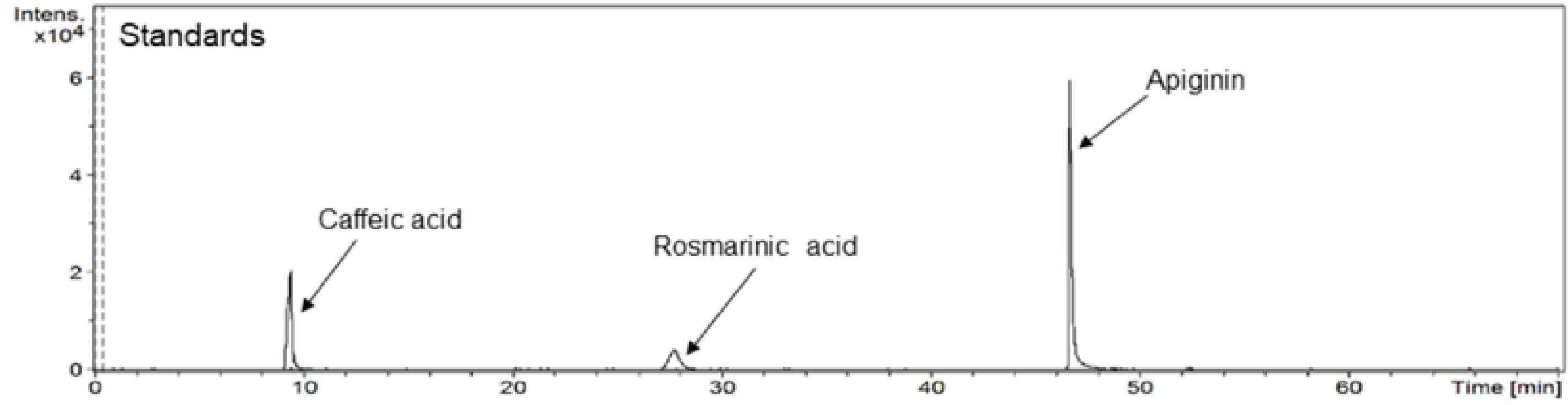

B

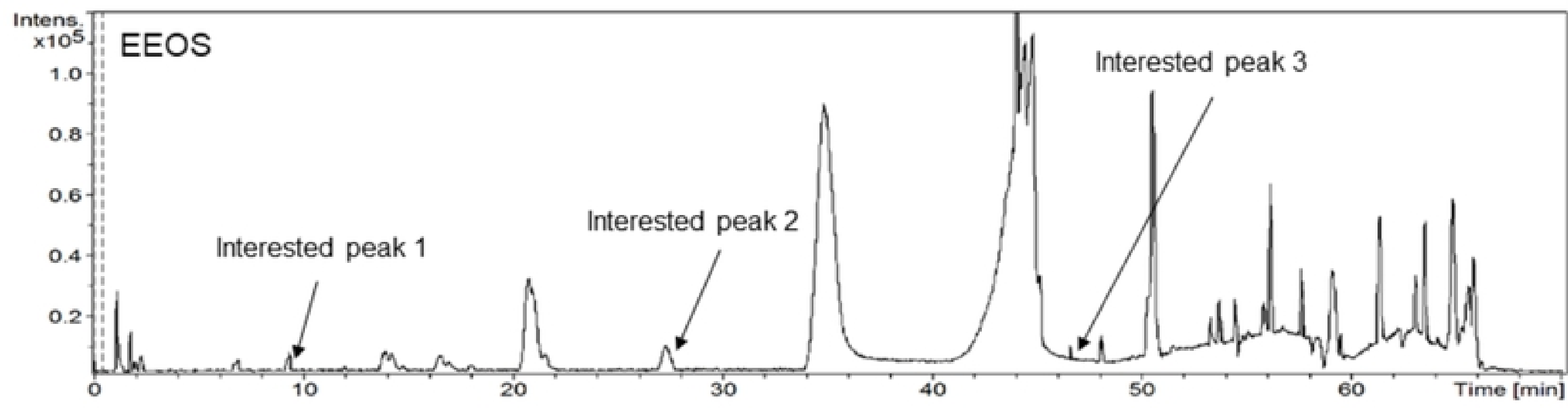

Fig 4 


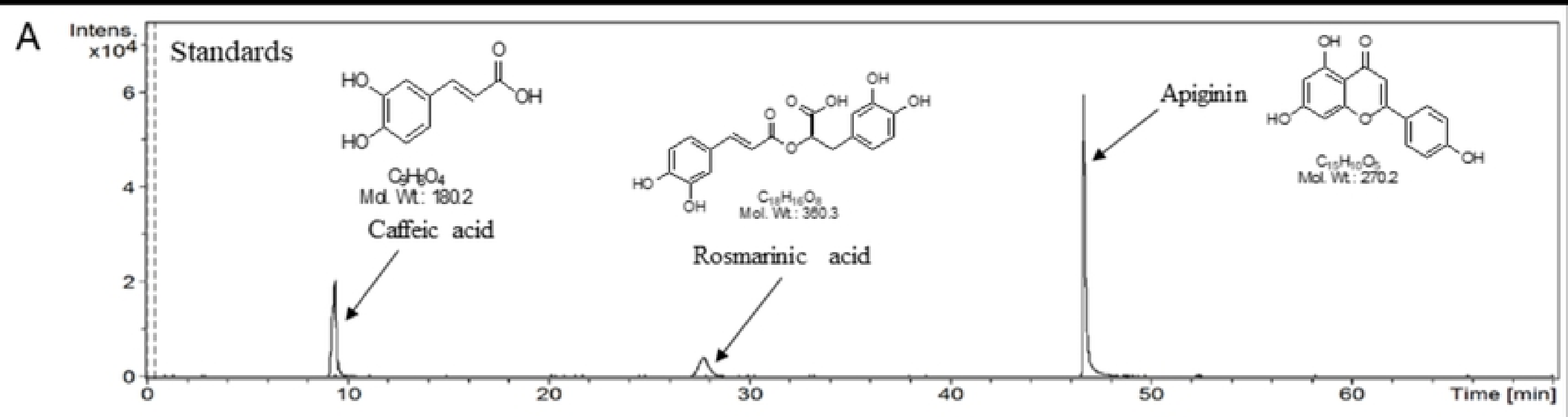

B $\begin{array}{r}\text { Intens } \\ \times 10^{5}\end{array}$
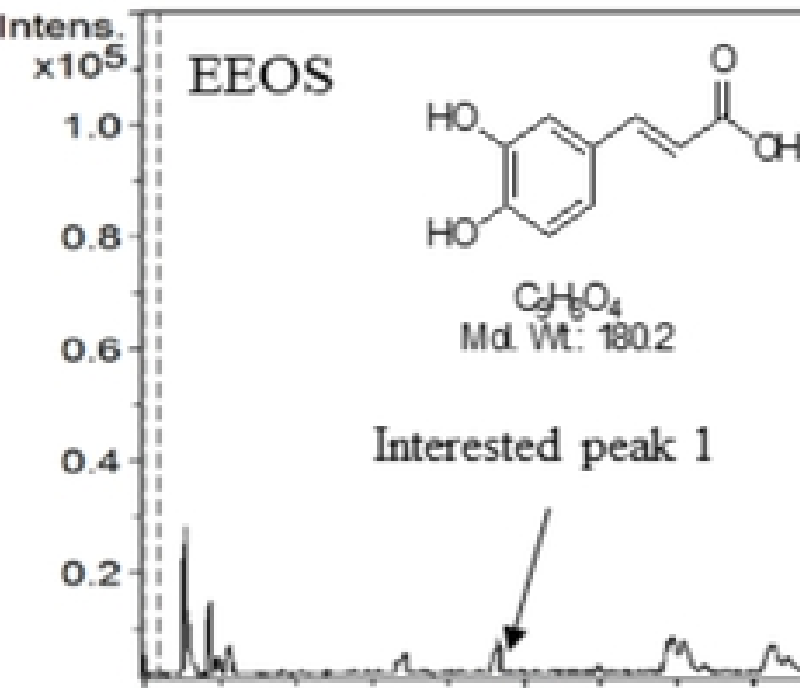

Interested peak 1

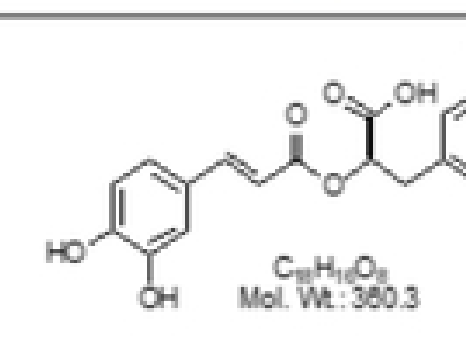

Interested peak 2

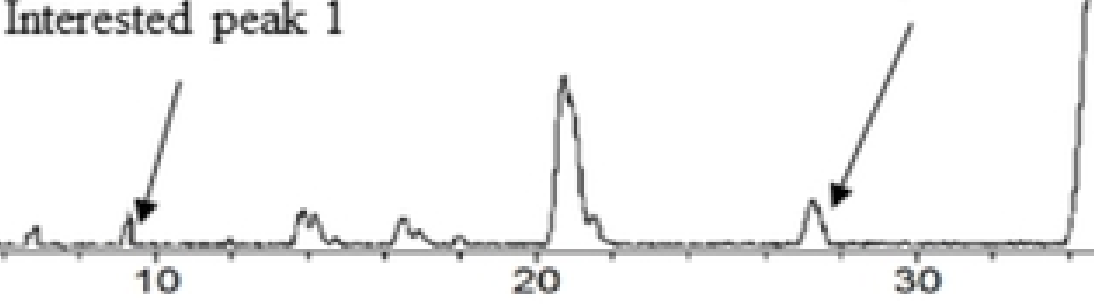

C

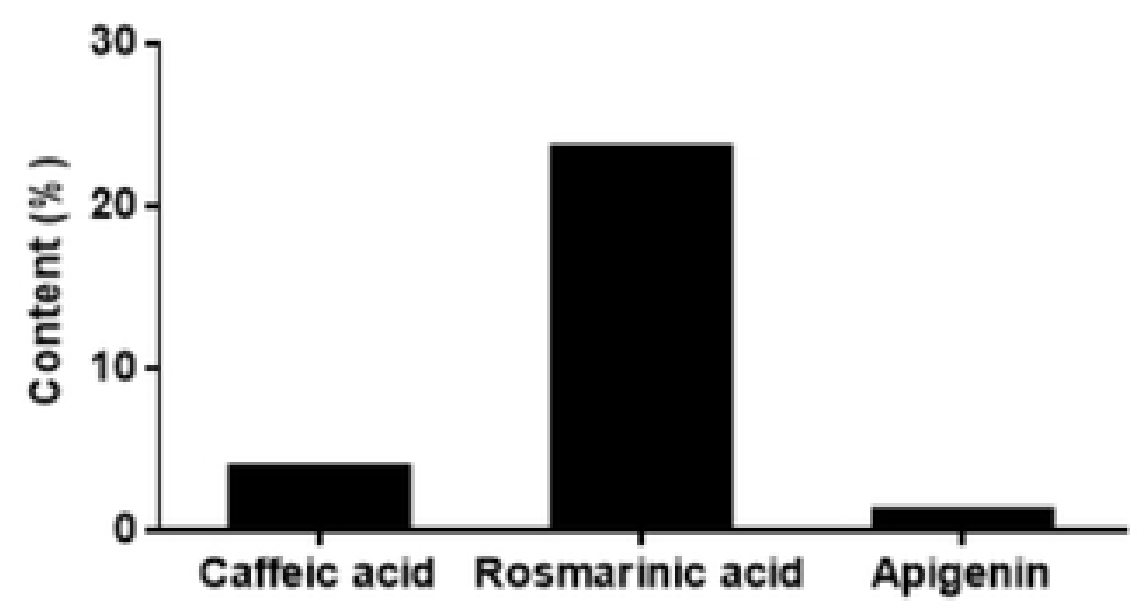

Fig 5 